\title{
How Have Shanghai, Saudi Arabia, and Supply Chains Affected U.S. Inflation Dynamics?
}

Kristin J. Forbes

This article is based on the Homer Jones Memorial Lecture delivered at the Federal Reserve Bank of St. Louis, May 16, 2018.

Understanding and forecasting inflation has always been a key focus of macroeconomics and monetary policymaking. Historically, many macroeconomists and central banks have relied on the "Phillips curve" framework for this purpose. Recently, however, the Phillips curve framework has not been performing well. This article examines a number of possible explanations for the breakdown of the "Phillips curve" relationship between slack and inflation. These explanations include the possibility that the curve may have flattened or shifted, that standard measures may not be capturing key aspects of the relationship, or that a series of "unfortunate" and unprecedented events may have obscured the underlying relationship. Each of these explanations has some merit and support, but each seems unable to explain how inflation dynamics have evolved over the past decade. This article suggests that what is missing is a more comprehensive treatment of how globalization has affected domestic prices, through channels such as increased trade flows, the greater economic heft of emerging markets, and increased ease of using global supply chains to shift parts of production to cheaper locations. This greater role for globalization in explaining inflation, however, does not mean that the standard Phillips curve framework is "dead." Rather, macroeconomists and monetary policymakers should update their existing models in two key ways: to include global parameters more explicitly and allow these parameters to adjust over time with the world economy. (JEL E13, E37, E52, F44, F62)

Federal Reserve Bank of St. Louis Review, First Quarter 2019, 101(1), pp. 27-43. https://doi.org/10.20955/r.101.27-43

\section{INTRODUCTION}

Understanding and forecasting inflation has always been a key focus of macroeconomicsand central for institutions setting monetary policy. Recently, however, the basic frameworks and models used to understand inflation have not been performing very well. When the global Financial Crisis hit in 2008 and growth collapsed around the world, why didn't inflation fall further? How did the world avoid a period of deflation, as occurred during the synchronized

Kristin J. Forbes is the Jerome and Dorothy Lemelson Professor of Management and Global Economics at MIT's Sloan School of Management.

(c) 2019, Federal Reserve Bank of St. Louis. The views expressed in this article are those of the author(s) and do not necessarily reflect the views of the Federal Reserve System, the Board of Governors, or the regional Federal Reserve Banks. Articles may be reprinted, reproduced, published, distributed, displayed, and transmitted in their entirety if copyright notice, author name(s), and full citation are included. Abstracts, synopses, and other derivative works may be made only with prior written permission of the Federal Reserve Bank of St. Louis. 


\section{Figure 1}

\section{GDP Growth and Inflation: Advanced Economies-A Puzzle?}

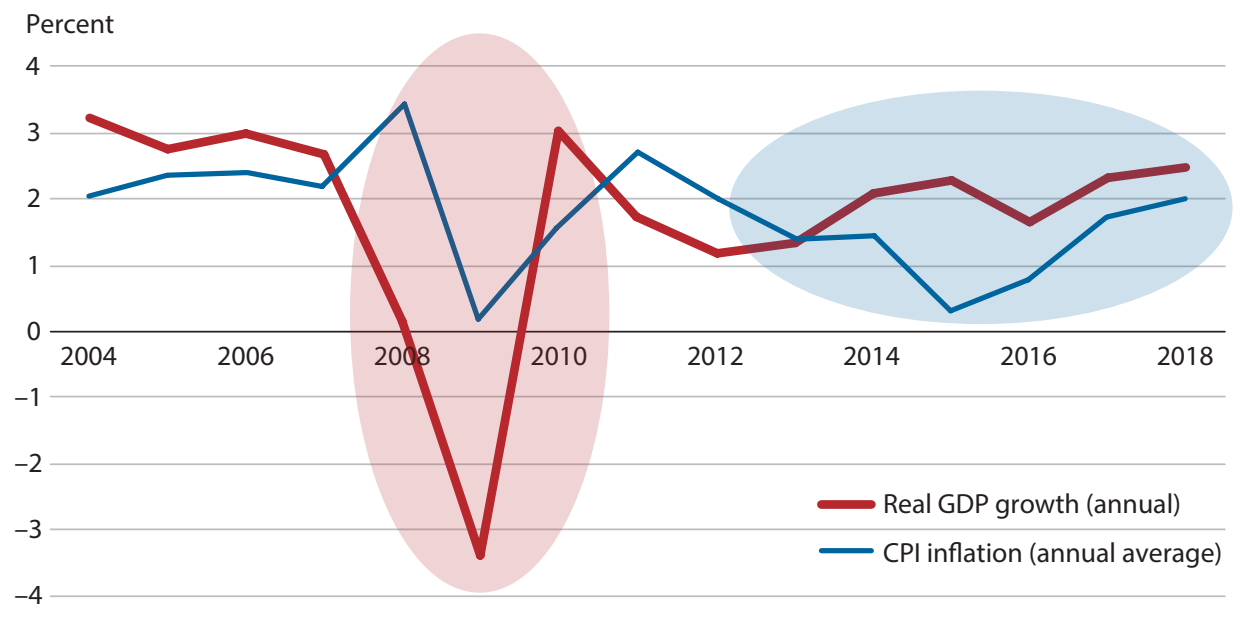

SOURCE: Based on data from the IMF (2018).

collapse in global economic output during the Great Depression? And more recently, as gross domestic product (GDP) growth has picked up in most advanced economies and unemployment has fallen-reaching record lows in some-why has inflation remained so low? Is this a sign of deep-seated vulnerabilities, such as the "secular stagnation" that was the theme of Larry Summers's (2016) recent Homer Jones lecture?

Figure 1 shows these puzzling patterns in a graph of annual real GDP growth and consumer price index (CPI) inflation for advanced economies. Why have the fluctuations in GDP growth over the past 15 years seemed to have so little effect on prices? There has been no shortage of speeches, commentary, and economic research trying to understand this disconnect. One of my favorite titles was "And Yet it Moves"1_a reference to Galileo's famous quote "Eppur si muove" - that he used when arguing that the earth moved around the sun. And just as the earth actually does move, the past few years have highlighted that inflation also moves, albeit not necessarily in the ways that our models have predicted.

A closer look at the distribution of CPI inflation rates in advanced economies (Figure 2) clearly shows this movement. Although the global economy has grown above 2 percent per year each year since 2009-and averaged growth of about 23/4 percent in 2014-15-CPI inflation was below 1 percent in over half of the advanced economies in 2014, 2015, and 2016. In 2015, CPI inflation was below 1 percent in over 80 percent of advanced economies and below zero (deflation) in over 30 percent. This is a sharp change from inflation hovering around 2 percent for much of the decade before the crisis. This is also a sharp change from 2008, when over 80 percent of the advanced economies had inflation over 3 percent.

Granted, optimists may focus on the last bar in the graph (for 2017), which suggests that the period of undesirably low inflation may be ending. In 2017, although inflation was still 
Figure 2

\section{Distribution of CPI Inflation Rates in Advanced Economies}

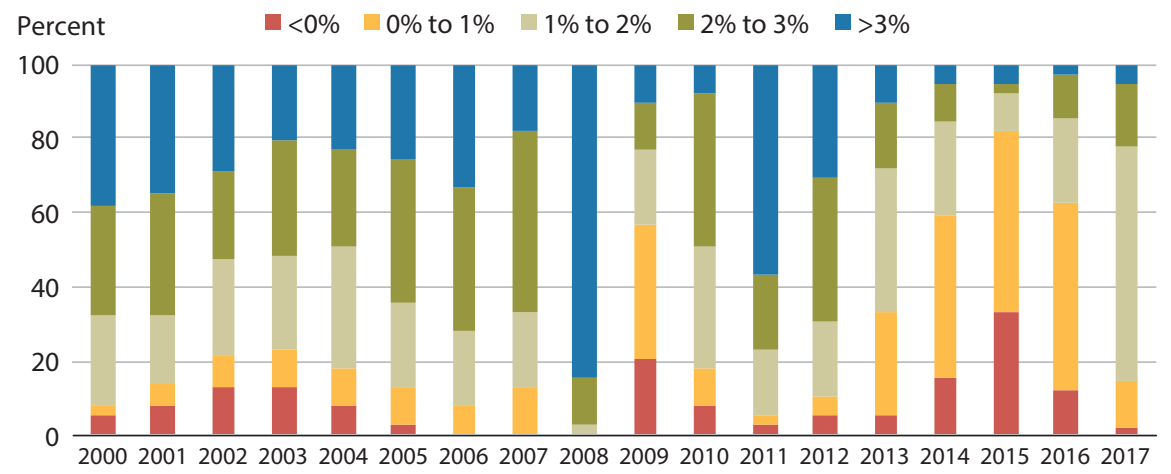

NOTE: Based on average annual inflation.

SOURCE: Based on data from the IMF (2018).

lower than many central banks' targets, it averaged between 1 percent and 3 percent for about 80 percent of the advanced economies. $\stackrel{2}{2}$ A meaningful part of this recovery in headline inflation rates, however, reflects a temporary boost from higher energy prices. What happens when energy prices stabilize? As the International Monetary Fund (IMF) highlighted in its April 2018 World Economic Outlook (Figure 3), core inflation, which tends to be a better determinant of underlying and sustainable inflation rates, is still only averaging about $1 \frac{1}{2}$ percent in advanced economies. There is still a lack of underlying inflationary pressures, despite unemployment being at the lowest level in a decade in many countries and below what is believed to be the NAIRU (non-accelerating inflation rate of unemployment) in a number of major economies. $\underline{3}$

What is perhaps most disconcerting for economists is the seeming breakdown of traditional models and economic relationships that are assumed to underpin the inflation process. Most prominent is the apparent breakdown of the Phillips curve. Throughout this article, I will use the term "Phillips curve" relationship broadly_not just to capture the relationship between unemployment and wage growth shown by William Phillips in his original curvebut instead to capture the more general relationship between the amount of slack (or spare 
Figure 4

\section{Model Breakdown?}

Flatlining

Inflation and cyclical unemployment, average across advanced economies, quarterly

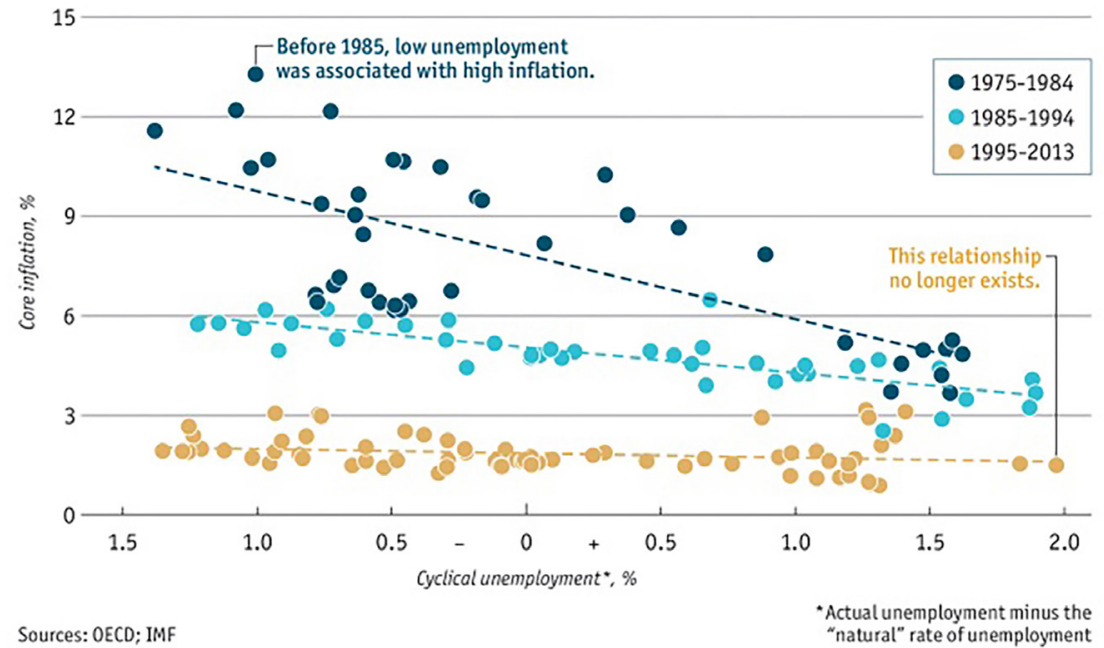

NOTE: OECD, Organisation for Economic Co-operation and Development.

SOURCE: Economist.com. "The Phillips Curve May Be Broken for Good." Daily Chart, November 1, 2017. ๑ The Economist Group Limited, London (2017).

capacity) in the economy and price inflation. There are a number of ways of measuring these concepts, details I'll get into below. But the basic concept is intuitive and at the core of most models of inflation. When most people who want to work are working, and there is little spare capacity in an economy, resource constraints tend to drive up wages and prices.

This Phillips curve relationship may sound obvious but has recently been hard to see in the data. Figure 4 shows a recent graph from The Economist that makes this point. The dots show one variant of this Phillips curve relationship-the relationship between cyclical unemployment and core inflation in advanced economies since the 1970s. The expected negative relationship between these measures of slack and unemployment existed from 1975-84 (the dark blue dots), but then weakened over the subsequent decade (the light blue dots), and further faded during the most recent period (the yellow dots). The relationship has recently been so weak that it almost disappears_or "flatlines"- so that the heading for the graph chosen by The Economist was "The Phillips curve may be broken for good." 4

Granted, this is not the first time that there has been soul searching about the accuracy of the Phillips curve. Figure 5A shows an early variant of the Phillips curve-graphed for the United States just as the concept became popular at the end of the 1960s. This clearly shows the expected negative relationship between unemployment and wage inflation. Figure 5B, however, shows what happened to this relationship over the next few decades. The Phillips curve appeared even more "broken" than today. 


\section{Figure 5}

\section{Model Breakdown}

\section{A. The Original Phillips Curve for the United States...}

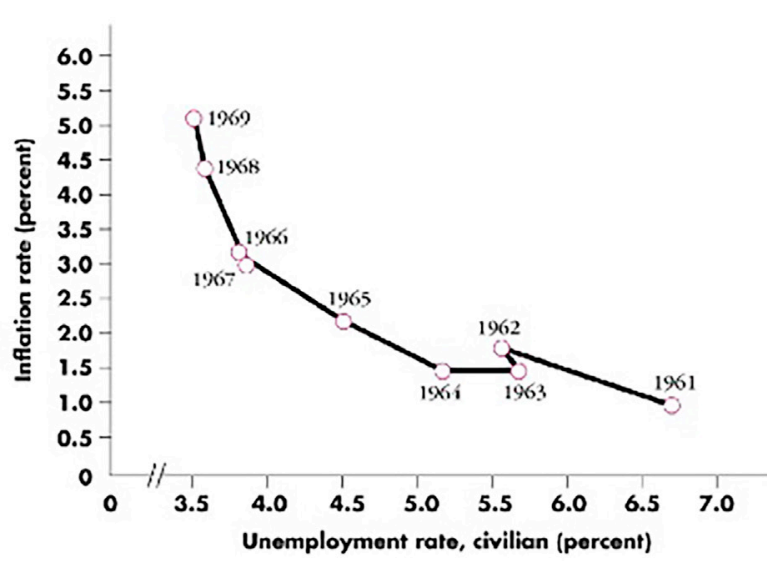

\section{B. Did Not Withstand the Test of Time}

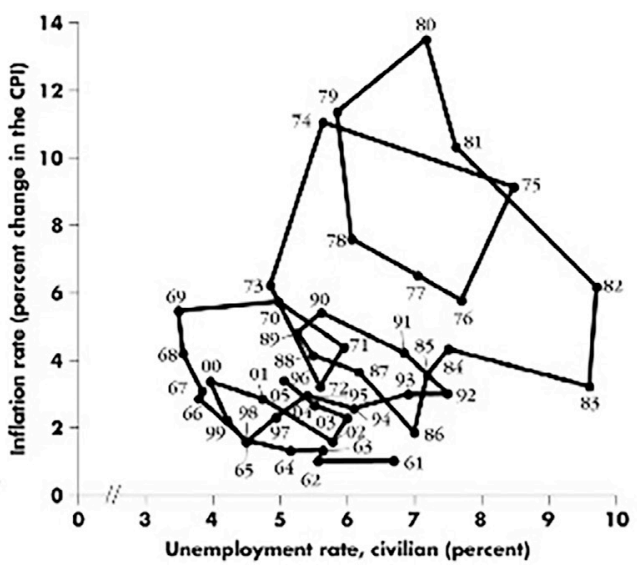

SOURCE: Dornbusch, Rudiger; Fischer, Stanley and Startz, Richard. Macroeconomics. 10th Edition. Chapter 6. McGraw Hill, 2008, pp. 124 and 126. OMcGraw-Hill Education.

These earlier breakdowns, however, were quickly explained with modest extensions to the framework-such as controlling for oil price shocks (or other supply shocks) that caused the Phillips curve to shift. More recently, concerns that the Phillips curve framework is no longer "fit for purpose" are more deep-seated. A Google search for articles that include the terms "dead" and "Phillips curve" yields over 1,000 hits. Is the Phillips curve framework broken for good?

This is the key theme that I will explore in the rest of this article. Has something changed so that the framework central for thinking about inflation dynamics is no longer useful? Have changes in the global economy_-in Shanghai (i.e., emerging markets), in Saudi Arabia (i.e., oil and commodity markets), and in supply chains (i.e., production processes) - affected inflation dynamics? If these changes in the global economy are incorporated into our frameworks for understanding inflation - do the old relationships still apply? Can we simply extend our old frameworks rather than throw them away?

In order to answer these questions, the remainder of the article is divided into four sections. Section II briefly summarizes key arguments why the Phillips curve framework may appear broken today. Section III proposes an alternative explanation: the need to add a more comprehensive treatment of changes in the global economy. Section IV provides some empirical evidence to support the growing role of international factors and globalization in explaining inflation dynamics. Section V concludes, tying together the pieces of evidence that suggest a better incorporation of the roles of "Shanghai, Saudi Arabia, and Supply Chains" can go some way toward improving our understanding of recent inflation dynamics. 


\section{CHALLENGES TO THE CURRENT PHILLIPS CURVE FRAMEWORK}

At the core of most inflation models are three key variables: the amount of slack in the domestic economy (often measured by the output gap or unemployment gap), inflation expectations (and/or lagged inflation), and supply shocks (usually measured by oil prices or import prices). This basic framework has worked fairly well during some periods, but at other times has been less successful, generating a number of ideas for improvement. $\underline{5}$ For example, Ball and Mazumder (2015) highlight the need to add time variation to the relationship between unemployment and inflation, while Krueger, Cramer, and Cho (2014) suggest focusing on short-run unemployment instead of long-run unemployment to capture slack. Recently, Coibion and Gorodnichenko (2015) suggest focusing on household inflation expectations instead of other measures, and Stock and Watson (2018) suggest focusing on more "cyclically sensitive" measures of inflation. After reviewing this literature, one cannot help but sympathize with the interpretation in Stock and Watson (2010), that the history of the Phillips curve is "one of apparently stable relationships falling apart upon publication" (p. 212).

What can explain the recent breakdown of the basic Phillips curve relationship between economic slack and inflationary pressures? The current state of debate focuses on five (partially overlapping) explanations: the relationship is dead, the curve has flattened, key concepts are not measured accurately, the curve has shifted, and the relationship has been obscured by a series of "unfortunate events." Let me take each explanation in turn.

1. Dead. The first explanation is that the "Phillips curve" tradeoff between economic slack and inflation no longer exists. People supporting this argument often suggest we should discard the old framework and start afresh. I don't believe this argument-for reasons that I will discuss in more detail below-so I will not spend very much time on it. Intuitively, there must be some point at which a lack of people to fill job vacancies causes companies to start to pay more, eventually translating into higher wage and price inflation. If there are no more resources (whether workers or other materials) to produce items that people want to buy, and companies are running at maximum capacity, it is hard to believe that they will not eventually start to raise prices. This basic relationship may have evolved over time, and may be hard to measure, but I find it hard to believe that it is entirely "dead."

2. Flattened. A second possible explanation is that the Phillips curve has flattened, such as indicated in Figure 4. There are a number of reasons why this might be happening. For example, the nature of work is changing. Unions have become less powerful in some countries (such as the United States). Fewer jobs are long-term relationships between one company and a set of workers, and instead more jobs are part of the "sharing economy," such as people driving for Uber. This more disperse nature of work and greater disconnect between workers and their employees would reduce workers' bargaining power. Also, as populations age, older workers may be more reticent to switch jobs, reducing their bargaining power in wage negotiations as their threat of leaving and switching jobs is less credible. These are only a few examples, but any of these effects could weaken the relationship between unemployment and wage growth, causing the Phillips curve to "flatline." 
3. Data and Measurement Issues. A third set of arguments is that the relationship between unemployment and inflation still exists (whether "flatter" or not), but we are not measuring key variables correctly. For example, in the United States, slack is usually assessed using the unemployment rate-which is currently very low and suggests little (if any) slack in the economy. This statistic misses a large pool of "discouraged" workers, however, who have stopped actively looking for work and are therefore no longer counted as being in the labor force. These workers could still be available for certain jobs and therefore reduce the pressure for companies to raise wages despite the low reported unemployment rate. $\frac{6}{}$ In the United Kingdom, as the unemployment rate has fallen, the most recent hires have tended to have less experience, skills, education, and training - traits which are all reflected in lower wages. When these new hires are added to the average wage pool, this mechanically lowers average wages and wage growth. Work by the Bank of England shows that when you adjust for these types of relative skill differentials in the composition of the labor force, it can explain a meaningful portion of the seeming puzzle of "missing" wage growth. ${ }^{7}$ These technical measurement issues can therefore be important and help explain some of the Philips curve puzzle.

4. Shifted. A fourth set of explanations for the apparent breakdown in the Phillips curve is that it may have "shifted" rather than "flattened"-as happened during the oil price shocks in the 1970s and 1980s (shown in Figure 5B). The Phillips curve could be shifting for a number of reasons. For example, productivity growth has fallen sharply in most advanced economies, and since pay is partly determined by how productive workers are each year, the fall in productivity growth would lower wage growth for any level of unemployment. Stricter requirements on access to unemployment benefits or income support could have increased the incentive to work, also shifting down the curve. Saunders (2018) provides graphical evidence from the United Kingdom that the Phillips curve has been "shifting" as well as flattening, suggesting that the relationship between unemployment and wages still exists, but just moves around over time.

5. "Unfortunate Events." A final set of theories explaining the seeming breakdown in the Phillips curve relationship is what I refer to as a "series of unfortunate events" for shorthand-a reference to the famous book series by Lemony Snicket. 8 The past decade has certainly been an era of unprecedented and unexpected events-even if all are not "unfortunate." For example, consider the three years when I was serving on the Monetary Policy Committee at the Bank of England. My term began in the summer of 2014, just as oil prices had begun to plunge (and would continue to drag on inflation for over two years) and just before the Scottish referendum on remaining in the United Kingdom. Less than a year later, there was a tight U.K. general election followed by an acceleration of capital outflows from China (which raised concerns about the global economy) and a period of tense negotiations with Greece on debt restructuring (which raised concerns about the future of the euro area). Then the United Kingdom announced a referendum on remaining in the European Union, and the surprising vote for "Brexit" prompted a leadership change and another general election. Each of these events generated a substantial degree of uncertainty-likely making companies more reluctant 
to agree to higher wages or raise prices. These types of events undoubtedly weakened the usual relationship between slack and inflation.

These different explanations for why the Phillips curve relationship between unemployment and inflation may have seemed to break down each appear to have some merit. Each has some empirical support in various research papers. The combination of the last four arguments undoubtedly goes some way to explaining the seeming breakdown in the expected relationship between slack and inflation. There is one import ant set of issues missing from this list, however, as well as from most discussions of the breakdown of the Philips curve: changes in the global economy.

\section{ROLE OF GLOBALIZATION}

Over the past few decades, globalization has proceeded at a rapid pace. Many changes in Shanghai, Saudi Arabia, and supply chains could influence the inflation process-including in ways that are not currently captured in the standard Phillips curve framework. This section discusses how various aspects of globalization, such as the greater role for emerging markets, increase in global trade flows, and greater use of supply chains, have been affecting commodity markets, worker bargaining power, and producer pricing decisions. The next section provides empirical evidence that this impact of globalization on inflation is not just theoreticalbut important and growing over time.

This idea that globalization may be affecting the inflation process is not new. In the mid2000s, several prominent policymakers gave speeches questioning whether increased globalization was helping moderate inflation pressures at that time. - The corresponding discussion generally concluded that although globalization was an important phenomenon, it appeared to have had only limited effects on the inflation process. Ball (2006, abstract) summarizes the current debate in an essay on whether the "globalization of the U.S. economy has changed the behavior of inflation" and summarizes the results of his tests as "no, no, and no." The role of globalization in inflation dynamics received less attention during and after the global Financial Crisis. Only recently, as inflationary pressures have remained muted in a number of economies despite minimal slack and a broad-based recovery, is the role of globalization in inflation dynamics beginning to regain attention. $\underline{10}$

One of the most striking changes in the global economy since the early 1990s has been the increased role of emerging economies. In 1990, advanced economies produced about 64 percent of global GDP and emerging markets about 36 percent. 11 In 2018, the IMF has predicted that this will almost reverse-with advanced economies producing only about 40 percent of global GDP and emerging markets about 60 percent. Emerging markets have accounted for over 75 percent of global growth since the crisis, with just one emerging market-Chinaresponsible for about one-third of global growth since then. Emerging markets also tend to use natural resources and commodities more intensively and are the key source of demand for commodities, contributing to a stronger link between global commodity prices and the growth dynamics in emerging markets. $\underline{12}$ This link between commodity prices and cyclical 
activity in major emerging markets has contributed to sharp swings in commodity prices and increased the role of commodities in inflation dynamics-especially as the effects of commodity prices on inflation tend to be nonlinear and larger after sharper price swings. $\underline{13}$

A related change in the global economy is the notable increase in global trade flows over the past 25 years-and not just through trade with emerging economies. According to the IMF, total global trade (exports plus imports) as a share of global GDP has increased from about 39 percent in 1990 to 56 percent in 2016. As the role of exports increases for a given economy, demand in global markets will likely play a greater role in national income and price setting by domestic companies. Similarly, as the role of imports increases, domestic inflation will be more affected by global prices, as imported goods constitute a larger share of the basket of goods purchased by consumers (and used to calculate inflation). A larger role for traded goods could also cause exchange rate movements to have larger effects on domestic prices and the pricing decisions by local companies.

Other closely related aspects of globalization are the ease of developing supply chains around the world, as well as the increased competition from foreign companies (and especially low-cost items from emerging markets). Both of these changes affect companies' pricing power and decisions on how to structure production. For companies that export or compete with imports, pricing decisions must take greater account of prices from foreign competitors. Even holding trade flows constant, greater "contestability" from global products will matter (Benigno and Faia, 2010). As it becomes easier to shift activities abroad-even just small stages of the production process-domestic costs will be more closely aligned with foreign costs. $\frac{14}{}$ This ease of shifting production to where it can be done at the lowest cost could particularly affect the bargaining power of workers. Increased imports from low-wage countries and more competition in traded goods could make it more difficult for domestic companies to raise prices and wages-even when there is little slack in local labor markets. $\frac{15}{}$ The increased mobility of workers, including the possibility of increased immigration to help fill job vacancies, could further reduce worker bargaining power.

Each of these aspects of globalization could change the relationship between slack and inflation-developments not currently incorporated in standard Phillips curve models. These changes in the global economy could even imply that slack in your own economy is a less important determinant of inflation and, instead, slack and labor market dynamics in the rest of the world may be increasingly relevant. $\underline{16}$

Put slightly differently, instead of simply focusing on dynamics in the local economy when modeling inflation, has globalization made it more important to consider global developments? For example, is rapid growth in other countries generating increased demand for a country's products? Is there excess capacity in the rest of the world-so that a local company could shift production elsewhere to keep costs down? Should "slack" be measured on a global basis, instead of just in the domestic economy? How is the increased competition in global markets, and greater volatility in commodity prices, affecting how companies set prices? And last, but certainly not least, if these different global factors are becoming more important in the inflation process, are they simultaneously reducing the role of domestic variables-such as domestic slack and the bargaining power of domestic workers? 
It is noteworthy that despite the substantial amount of attention paid to globalization in a wide array of venues, there has been little attempt to better incorporate these changes in the global economy into standard frameworks for modeling inflation. The most common approach for modeling inflation (shown in more detail in the next section) continues to be to control for domestic slack, inflation expectations, and import prices (or just oil prices). The assumption underlying this approach is that these variables are "sufficient statistics" to capture any changes in the global economy that could affect pricing dynamics. $\frac{17}{\underline{ }}$

The range of ways in which globalization could be affecting inflation discussed in this section, however, suggests that this "sufficient statistic" treatment is unlikely to be "sufficient." Foreign prices may act as a counterweight on domestic pricing, even if goods are not traded and therefore not captured in import prices. Measures of slack in the domestic economy may not capture the expected evolution of slack in other economies that will affect import prices going forward, or the ease of shifting parts of production elsewhere if workers bargain for higher wages. Separately controlling for energy prices from non-energy commodity prices could better identify changes in import prices corresponding to global demand rather than just oil prices (which can be affected by geopolitical events). This should better capture the increased volatility in commodity prices linked to changes in demand by emerging markets. A more explicit and comprehensive treatment of these types of changes in the global economy could be important for understanding inflation dynamics.

\section{EMPIRICAL EVIDENCE: THE ROLE OF GLOBALIZATION}

There are convincing arguments why globalization could be affecting inflation dynamics, but is there empirical evidence? This section uses two very different empirical approaches to provide support for the role of globalization in inflation dynamics: principal components and regression analysis. These empirical results are drawn from a longer and more comprehensive analysis in Forbes (2018), which includes details on the sample, data, and estimation techniques.

To begin, Figure 6 shows the first principal component for four different measures of inflation for a sample of advanced economies and major emerging markets over five-year windows since 1990. $\frac{18}{}$ The "principal component" is basically the shared movement in changes in the countries' quarterly inflation rates. The measures of inflation are CPI, core inflation (CPI inflation less food and energy prices), producer price inflation (PPI), and wage inflation.

The principal component for the CPI-the main measure of inflation on which most central banks focus $\frac{19}{}$ - is about 60 percent at the end of the sample. This means that 60 percent of the movement in each country's inflation rate is synchronized, that is, shared globally with the other countries in the sample. This indicates a substantial amount of comovement in CPI inflation rates around the world at the end of the sample. The line for PPI inflation bounces around 60 percent for the entire period, also suggesting a high degree of comovement in the prices producers have been paying for inputs since 1990. This is not surprising given the international market for many inputs for production (such as steel and oil). In contrast, the principal components for wages and core inflation end the sample at much lower levels-between 


\section{Figure 6}

\section{Global Principal Components in Inflation Over Time: Fraction of Variance Explained by First Principal Component for Advanced Economies}

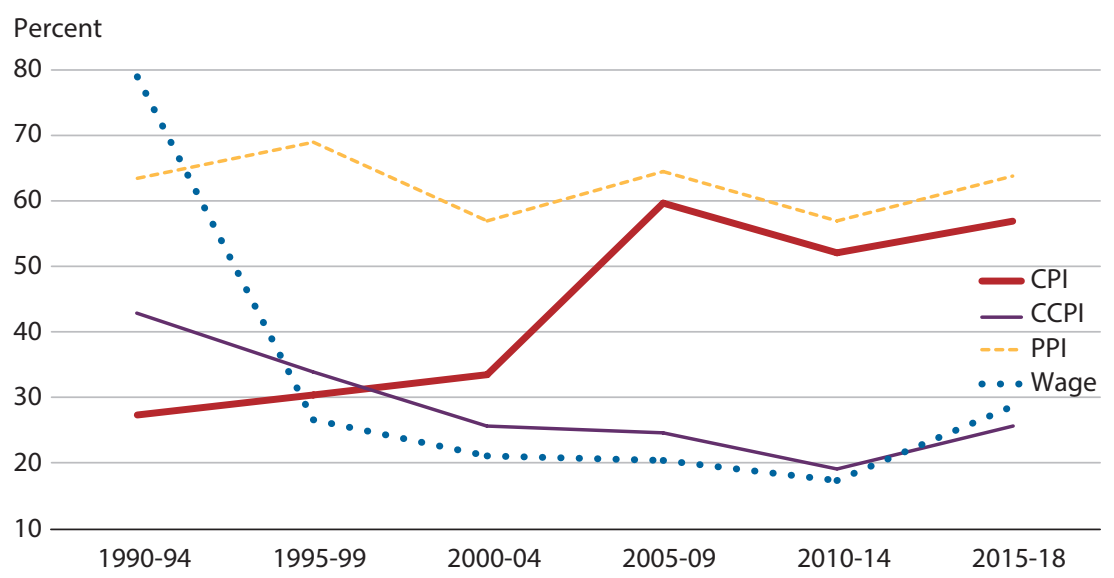

NOTE: Fraction of variance explained by the first principal component for the relevant measure of inflation. All measures of inflation are quarterly, annualized, and seasonally adjusted. CPI is headline CPI, CCPI is core CPI, PPI is producer price inflation, and Wage is a measure of private sector wage growth.

20 percent to 30 percent since 2010 - indicating that these prices move more independently across countries.

What is perhaps most interesting, however, is how these estimated principal components have evolved over time. The shared principal component of CPI inflation was quite low in the early 1990s, at about 30 percent, but has more than doubled since to about 60 percent. This suggests that something has changed in the dynamics of headline inflation rates. Headline inflation rates move more in sync now than in the 1990s. A majority of the movements in a country's headline inflation rate correspond to movements in the rest of the world. Yet in contrast, core inflation and wage inflation move more independently in countries around the world - with the degree of synchronization falling instead of rising over time.

This analysis doesn't provide answers to why certain measures of inflation are more synchronized, however, or why the shared global components have changed over time for some measures. To understand these patterns and divergent trends, it is useful to shift to more formal regression analysis. This would allow tests if different variables-and especially different global variables-could explain these trends in the comovement of inflation rates around the world. Is globalization an important factor driving synchronized movements in CPI inflation rates in so many countries? Have changes in the global economy caused some of these changes over time?

More specifically, and building on the discussion in the previous section, what is the impact of the greater heft of emerging markets and corresponding increase in commodity price volatility? What is the impact of the increased share of trade relative to GDP and corresponding increase in trade competition and use of supply chains? Is there a greater role for 
Table 1

\section{Phillips Curve Estimates}

\begin{tabular}{lcc} 
& CPI inflation & Core inflation \\
\hline Inflation expectations & $0.670^{* * *}(0.073)$ & $0.462^{* * *}(0.052)$ \\
\hline Lagged inflation & $0.646^{* * *}(0.034)$ & $0.704^{* * *}(0.024)$ \\
\hline Domestic output gap & $0.094^{* * *}(0.017)$ & $0.084^{* * *}(0.012)$ \\
\hline Real exchange rate & $-0.020^{* * *}(0.006)$ & $-0.013^{* * *}(0.004)$ \\
\hline World output gap & $0.072^{* * *}(0.023)$ & $0.043^{* * *}(0.012)$ \\
\hline World oil prices & $0.002^{* * *}(0.001)$ & $0.001^{* *}(0.000)$ \\
\hline World commodity prices & $0.010^{* * *}(0.002)$ & $0.003^{* *}(0.001)$ \\
\hline World PPI dispersion & $0.114^{* * *}(0.034)$ & $0.019(0.028)$ \\
\hline Adjusted $R^{2}$ & 0.55 & 3,038 \\
\hline $\begin{array}{l}\text { Number of observations } \\
\text { NoTE: Regressions of quarterly, annualized, seasonally adjusted inflation from 1990-2017 for a sample of 43 countries }\end{array}$ \\
$\begin{array}{l}\text { with fixed coefficients over the full period. }{ }^{* *} \text { is significant at the } 1 \text { percent level and }{ }^{* *} \text { at the } 5 \text { percent level. Standard } \\
\text { errors are in parentheses. }\end{array}$ \\
\begin{tabular}{l} 
SOURCE: Replicated from Forbes (2018). \\
\hline
\end{tabular}
\end{tabular}

global slack—and possibly reduced role for domestic slack? How have Shanghai (i.e., emerging markets), Saudi Arabia (i.e., oil and commodity markets), and supply chains (i.e., changes in production patterns) affected inflation?

To capture these various ways in which globalization may be affecting the inflation process, I estimate a standard Phillips curve model but add a set of variables to more comprehensively control for changes in the global economy. More specifically, I estimate inflation in different countries as a function of three standard Phillips curve variables: the domestic output gap (the key variable on which most discussion focuses), inflation expectations, and lagged inflation. $\underline{20}$ Then I add five global variables: exchange rates $\underline{21}$, the world output gap, oil prices, commodity prices, and a measure of global producer price dispersion (to capture the role of supply chains, as in Auer, Levchenko, and Sauré, 2016). .22 I estimate the model for quarterly CPI and core inflation from 1990 to 2017 for a cross-section of mainly advanced economies.

Table 1 shows the results, replicated from Forbes (2018) for both CPI and core inflation. The positive and significant coefficients on inflation expectations, lagged inflation, and domestic slack all suggest that these standard domestic variables included in most inflation models still play a significant role in explaining inflation dynamics. $\underline{23}$ The significant coefficients on almost all of the global variables, however, suggest that these global factors are also important. More specifically, exchange rate depreciations, larger world output gaps, higher oil and commodity price inflation, and less competitive producer pricing are all correlated with higher CPI and core inflation.

One challenge with these results, however, is that they treat the effects of each of the variables (both domestic and global) as constant over time. Yet the discussion in Section III 
highlighted how globalization may have changed the relationship between the global factors and inflation, and the discussion in Section II highlighted how even the relationships between the domestic factors and inflation may have changed over time. A number of academic studies have also highlighted the instability of the coefficients in Phillips curve models. $\underline{24}$

To test for changes in the role of the global factors affecting inflation, I estimate the same Phillips curve model from Table 1, except now estimate rolling regressions over eight-year windows instead of assuming that the relationships are fixed over time. This extension confirms that the role of many of these variables changes over time. To take one example, Figure 7 shows the resulting rolling coefficients on commodity price inflation (the role of "Shanghai"). The figure shows the median coefficient

\section{Figure 7}

\section{Dynamics in the Phillips Curve- Rolling Coefficient on Commodity Inflation}

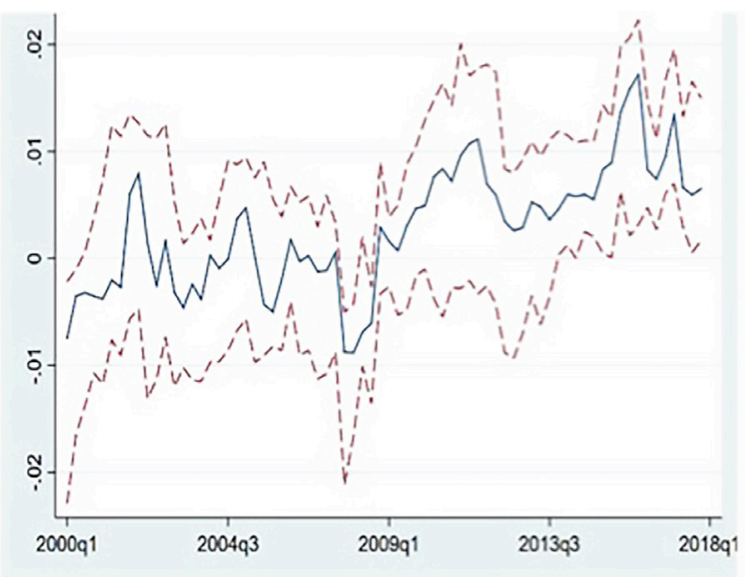

NOTE: Reports median coefficient from rolling regressions for the specification in Table 1 using eight-year windows. Regression is on quarterly, annualized CPI inflation from 1990 2017, estimated separately for each country. Dashed red lines are the 33 percent and 66 percent of the distribution. Commodity prices measured relative to corresponding quarterly $\mathrm{CPI}$ inflation.

SOURCE: Replicated from Forbes (2018).

estimate when the model is estimated separately for each country for which data are available, with the dashed lines showing the coefficient estimates for 33 percent and 66 percent of the distribution. This coefficient on commodity prices increases sharply after the global Financial Crisis and then increases again in the later part of the sample. The relationship between a given change in commodity prices and CPI inflation has increased over the past decade. ${ }^{25}$ Similar graphs for the other variables also show sharp movements over time.

These types of figures (with the full set shown in Forbes, 2018) suggest that global factors can significantly affect inflation, but that their role (as well as that of domestic factors) can change meaningfully over time. More formal regression analysis that tests for any significant change in the role of the global variables over time further supports the increased role of these global factors in explaining CPI inflation over the past decade.

For example, if I repeat the regression of Figure 7, but now allow the role of the different variables to change over the more recent period from 2007-17, statistical tests indicate that the role of the global variables has increased significantly for CPI inflation. $\underline{26}$ More specifically, the world output gap and world commodity prices appear to have had a stronger positive impact on CPI inflation over the past decade. In fact, when the role of these two global variables is allowed to change over time, global slack and commodity prices are generally not estimated to be important in the pre-crisis period, but are significant over the past decade (or even just over the past few years). This could be why global variables were not a focus of Phillips curve-based inflation models before the Financial Crisis; their role was less important. 
Finally, it is worth noting that although the world output gap and commodity prices appear to have had a greater role in determining CPI inflation in the past decade, these global variables do not appear to have played a significantly greater role in driving core inflation. This could explain the divergent patterns in the global principal component for different inflation rates shown in Figure 6. The greater role of global variables to CPI inflation over the past decade could have driven the increased synchronization in CPI inflation rates over this period, but since the role of these global variables was smaller and changes less for core inflation (as well as wage inflation), they would not have generated the same increase in comovement. This does not mean, however, that global variables are unimportant for explaining core inflation. Instead, the regression results that allow the role of the different factors to change over the past decade continue to find an important role for exchange rates in driving core inflation. Since exchange rates often move in different directions in different countries, this could also explain the less synchronized movements in core inflation in countries around the world.

\section{CONCLUSIONS}

Standard frameworks for understanding inflation have not been performing well. There are a number of possible explanations for the seeming breakdown of the "Phillips curve" relationship between slack and inflation: The curve may have flattened or shifted, standard measures may not be capturing key aspects of the relationship, or a series of "unfortunate" and unprecedented events may have obscured the underlying relationship. Each of these explanations has some merit and support—but something still seems to be missing from our understanding of inflation dynamics over the past decade.

This article suggests that the missing component is a more comprehensive treatment of globalization. The global economy has evolved in many ways, such as through increased trade flows, a greater heft of emerging markets, and increased use of supply chains. Many of these changes will affect inflation dynamics, in both how companies make pricing decisions and how effectively workers can bargain for higher wages. These changes in the global economy are multifaceted-from the functioning of commodity and oil markets, to the role of exchange rate movements and global slack, to how companies can more easily shift parts of production around the world.

This greater role for globalization in explaining inflation, however, does not mean that the standard Phillips curve framework is "dead." It does not imply that we should discard our old models. Instead, we should update the models to include global parameters more explicitly and allow these parameters to adjust over time with the world economy. Just as emerging markets, commodity markets, and patterns of production have evolved over time, it is time to more explicitly include a role for "Shanghai, Saudi Arabia, and supply chains" in our inflation frameworks. 


\section{NOTES}

1 Miles et al. (2017).

$\underline{2}$ Economies are defined as "advanced" based on IMF definitions.

$\underline{3}$ This low rate of underlying inflation is also evident when inflation is decomposed into a slow-moving "trend" and shorter-term "cyclical" component, as shown in Forbes (2018) for a cross-section of countries using a model developed in Forbes, Kirkham, and Theodoridis (2018).

4 Economist.com (2017).

5 For recent overviews and key arguments, see Ball and Mazumder (2015); Blanchard (2018); Gordon (2013); Miles et al. (2017); and Stock and Watson (2010).

6 See Hong et al. (2018) for challenges in measuring slack.

7 See Abel et al. (2016).

8 See Forbes (2017) for more detail on this series of "unfortunate events" in the United Kingdom.

9 For example, see Bean (2006), Kohn (2006), and Yellen (2006). Also see Gamber (2001) and Ihrig et al. (2010).

10 See Borio (2017) for an overview of ways globalization may have changed the inflation process over time.

11 Based on IMF definitions and adjusting for purchasing power parity, which puts greater weight on emerging market output.

12 See World Bank (2018) and Miles et al. (2017) for additional evidence.

13 See Hamilton (2010) or a standard sticky-price model to explain these effects, such as Ball and Mankiw (1995).

14 See Wei and Xie (2018) and Auer, Levchenko, and Sauré (2016) for the evolving role of supply chains.

15 See Auer, Degen, and Fischer (2013) and Auer, Borio, and Filardo (2017).

$\underline{16}$ See Borio and Filardo (2007) for the first careful analysis and discussion of the role of global slack for inflation.

17 For an example of this line of reasoning, see Eickmeier and Pijnenbrug (2013).

18 The sample is primarily advanced economies but also includes a number of major emerging markets. The sample size ranges from 26 to 43 countries based on the year and measure of inflation. Also see Hakkio (2009) for another example of principal component analysis to understand inflation dynamics.

19 One notable exception is the United States, where the U.S. Federal Reserve focuses on core personal consumption expenditures.

20 Inflation expectations are the five-year-ahead forecast from the IMF's World Economic Outlook. The domestic output gap is measured as a principal component of seven measures of domestic slack. See Forbes (2018) for more details on variable definitions, sources, and summary statistics.

$\underline{21}$ Exchange rates incorporate a global and domestic component; but as they are usually not explicitly included in Phillips curve regressions, I include them as part of the nontraditional set of "global" variables. The exchange rate is the percent change in the real exchange rate index relative to two years earlier.

$\underline{22}$ The world output gap is reported by the Organisation for Economic Co-operation and Development. Oil and commodity prices are measured relative to the $\mathrm{CPI}$ or core inflation. The dispersion in producer prices is the change in the quarterly variance in PPI prices relative to four quarters earlier for all countries in the sample.

$\underline{23}$ It is important to note, however, that although the variables in Figure 7 are significant in the pooled cross-section results, when the same model is estimated for individual countries, the coefficients are less often significant, reflecting the diversity of country experiences. See Forbes (2018) for more detail on results by country.

$\underline{24}$ For example, see Albuquerque and Baumann (2017), Blanchard et al. (2015), and IMF (2016).

$\underline{25}$ Some of the shifts in the coefficients correspond to sharp movements in commodity prices, which would be consistent with nonlinear effects and sticky-price models in which firms are more likely to adjust prices after larger price movements. Some of the estimated effects of commodity price movements may also capture changes in growth prospects in emerging markets, a link that has increased over time (see World Bank, 2018).

$\underline{26}$ This involves adding interactions of each of the variables with a dummy variable equal to 1 for the past period. 


\section{REFERENCES}

Abel, Will; Burnham, Rebecca and Corder, Matthew. "Wages, Productivity and the Changing Composition of the UK Workforce." Bank of England Quarterly Bulletin, 2016:Q1, pp. 12-22; https://doi.org/10.2139/ssrn.2759723.

Albuquerque, Bruno and Baumann, Ursel. "Will US Inflation Awake from the Dead? The Role of Slack and NonLinearities in the Phillips Curve." European Central Bank Working Paper Series No. 2001, 2017.

Auer, Raphael; Borio, Claudio and Filardo, Andrew. "The Globalisation of Inflation: The Growing Importance of Global Value Chains." Bank for International Settlements Working Paper No. 602, 2017.

Auer, Raphael; Degen, Kathrin and Fischer, Andreas. “Low-Wage Import Competition, Inflationary Pressure, and Industry Dynamics in Europe." European Economic Review, 2013, 59(Issue C), pp. 141-66; https://doi.org/10.1016/j.euroecorev.2012.11.007.

Auer, Ralphael; Levchenko Andrei and Sauré, Philip. "International Inflation Spillovers through Input Linkages." Unpublished manuscript, University of Michigan, 2016.

Ball, Laurence. "Has Globalization Changed Inflation?" NBER Working Paper No. 12687, National Bureau of Economic Research, November 2006.

Ball, Laurence and Mankiw, Gregory N. "Relative-Price Changes as Aggregate Supply Shocks." Quarterly Journal of Economics, 1995, 110(1), pp. 161-93; https://doi.org/10.2307/2118514.

Ball, Laurence and Mazumder, Sandeep. "A Phillips Curve with Anchored Expectations and Short-term Unemployment." IMF Working Paper No. 15/39, International Monetary Fund, 2015.

Bean, Charles. (2006). “Globalisation and Inflation.” Bank of England Quarterly Bulletin, 2006 Q4, pp. 468-75.

Benigno, Pierpaolo and Faia, Ester. "Globalization, Pass-through and Inflation Dynamic." NBER Working Paper No. 15842, National Bureau of Economic Research, March 2010.

Blanchard, Olivier. "Should We Reject the Natural Rate Hypothesis?" Journal of Economic Perspectives, 2018, 32(1), pp. 97-120, ; https://doi.org/10.1257/jep.32.1.97.

Blanchard, Olivier; Cerutti, Eugenio and Summers, Lawrence. "Inflation and Activity: Two Explorations and Their Monetary Policy Implications," in Inflation and Unemployment in Europe: Conference Proceedings, ECB Forum on Central Banking. Frankfurt: European Central Bank, 2015; https://doi.org/10.3386/w21726.

Borio, Claudio. “Through the Looking Glass." BIS Lecture, September 22, 2017.

Borio, Claudio and Filardo, Andrew. "Globalisation and Inflation: New Cross-country Evidence on the Global Determinants of Domestic Inflation." BIS Working Papers No. 227, Bank for International Settlements, 2007.

Coibion, Olivier and Gorodnichenko, Yuriy (2015). "Is the Phillips Curve Alive and Well after All? Inflation Expectations and the Missing Disinflation." American Economic Journal: Macroeconomics, 7(1), pp. 197-232; https://doi.org/10.1257/mac.20130306.

Dornbusch, Rudiger; Fischer, Stanley and Startz, Richard. Macroeconomics. 10th Edition. Chapter 6. New York: McGraw Hill, 2008. pp. 124 and 126.

Economist.com. “The Phillips Curve May Be Broken for Good.” Daily Chart, November 1, 2017.

Eickmeier, Sandra and Pijnenburg, Katharina. "The Global Dimension of Inflation - Evidence from FactorAugmented Phillips Curves." Oxford Bulletin of Economics and Statistics, 2013, 75(1), pp. 103-22; https://doi.org/10.1111/obes.12004.

Forbes, Kristin. "Has Globalization Changed the Inflation Process?" Paper prepared for 17th BIS Annual Research Conference, Zurich, June 22, 2018.

Forbes, Kristin. "Failure to Launch." Speech at the London Business School, June 22, 2017; https://www.bankofengland.co.uk/speech/2017/failure-to-launch.

Forbes, Kristin; Kirkham, Lewis and Theodoridis, Konstantinos "A Trendy Approach to UK Inflation Dynamics." MIT Sloan Research Paper No. 5268-18, 2018.

Gamber, Edward and Hung, Juann "Has the Rise in Globalization Reduced U.S. Inflation in the 1990s?" Economic Inquiry, 2001, 39(1), pp. 58-73; https://doi.org/10.1093/ei/39.1.58. 
Gordon, Robert. "The Phillips Curve Is Alive and Well: Inflation and the NAIRU during the Slow Recovery." NBER Working Paper No. 19390, National Bureau of Economic Research, 2013.

Hakkio, Craig. "Global Inflation Dynamics." Working Paper No. 09-01, Federal Reserve Bank of Kansas City, 2009.

Hamilton, James. "Nonlinearities and the Macroeconomic Effects of Oil Prices." NBER Working Paper No. 16186, National Bureau of Economic Research, 2010.

Hong, Gee Hee; Kóczán, Zsóka; Lian, Weicheng and Nabar, Malhar. "More Slack than Meets the Eye? Wage Dynamics in Advanced Economies." IMF Working Paper No. 18/50, International Monetary Fund, 2018.

Ihrig, Jane; Kamin, Steven B.; Lindner, Deborah and Marquez, Jaime. "Some Simple Tests of the Globalization and Inflation Hypothesis." International Finance, 2010, 13(3), pp. 343-75; https://doi.org/10.1111/j.1468-2362.2010.01268.x.

International Monetary Fund. World Economic Outlook: Cyclical Upswing, Structural Change. April 2018.

International Monetary Fund. "Global Disinflation in an Era of Constrained Monetary Policy," in World Economic Outlook: Symptoms and Remedies. Chapter 3. October 2016.

Kohn, Donald. "The Effects of Globalization on Inflation and their Implications for Monetary Policy." Remarks at Federal Reserve Bank of Boston's 51st Economic Conference, June 16, 2006; https://www.federalreserve.gov/newsevents/speech/kohn20060616a.htm.

Krueger, Alan B.; Cramer, Judd and Cho, David. "Are the Long-Term Unemployed on the Margins of the Labor Market?" Brookings Papers on Economic Activity, Spring 2014, pp. 229-80; https://doi.org/10.1353/eca.2014.0004.

Miles, David; Panizza, Ugo; Reis, Ricardo and Ubide, Ángel. "And Yet It Moves: Inflation and the Great Recession." Geneva Reports on the World Economy No. 19, 2017.

Saunders, Michael. "The Outlook for Jobs and Pay." Speech at the Launch of Financial Intermediary and Broker Association at BAFTA, London, January 17, 2018; https://www.bankofengland.co.uk/speech/2018/michael-saunders-launch-of-financial-intermediary-and-broker-association.

Stock, James H. and Watson, Mark. "Modeling Inflation after the Crisis" in Proceedings of the Jackson Hole Symposium. Federal Reserve Bank of Kansas City, 2010, pp. 173-220; https://doi.org/10.3386/w16488.

Stock, James and Watson, Mark. "Slack and Cyclically Sensitive Inflation." Paper prepared for the "European Central Bank Forum on Central Banking," Sintra, Portugal, June 18-20, 2018.

Summers, Lawrence H. "Secular Stagnation and Monetary Policy." Federal Reserve Bank of St. Louis Review, Second Quarter 2016, 98(2), pp. 93-110; https://doi.org/10.20955/r.2016.93-110.

Wei, Shang-Jin and Xie, Yinxi. "On the Divergence between CPI and PPI as Inflation Gauges: The Role of Supply Chains." NBER Working Paper 24319, National Bureau of Economic Research, 2018.

World Bank. (2018). "The Role of Major Emerging Markets in Global Commodity Demand" in Global Economic Prospects, June 2018, pp. 61-90.

Yellen, Janet L. "Monetary Policy in a Global Environment." Speech delivered at the University of California, Santa Cruz, May 27, 2006; https://www.frbsf.org/our-district/press/presidents-speeches/yellen-speeches/2006/may/ monetary-policy-in-a-global-environment/. 
